\title{
Effectiveness of myo-inositol oxygenase in the early diagnosis of experimental acute kidney injury
}

\author{
Mertoglu $\mathrm{C}^{1}$, Ozmen $\mathrm{ZC}^{2}$, Firat $\mathrm{F}^{3}$, Arici A ${ }^{4}$, Unsal V², Erdemir F \\ Department of Clinical Biochemistry, Mengücek Gazi Training and Research Hospital, Erzincan \\ Binali Yildirim University, Erzincan, Turkey. drcumamert@hotmail.com
}

\section{ABSTRACT}

OBJECTIVES: The effectiveness of the myo-inositol oxygenase (MIOX) enzyme was investigated in the diagnosis of acute kidney injury (AKI).

METHODS: In total, 40 rats were divided into 5 groups $(n=8$, for each group) while left kidney ischemiareperfusion was implemented in groups 2, 3, 4 and 5. Group 1 was the control group. Group 2 underwent 1-hour ischemia and 2-hour reperfusion. Group 3 underwent 1-hour ischemia and 4-hour reperfusion. Group 4 underwent 2-hour ischemia and 2-hour reperfusion. Group 5 underwent 2-hour ischemia and 4-hour reperfusion.

RESULTS: Serum creatinine and blood urea nitrogen levels in all ischemia-reperfusion groups were higher than in the control group $(p<0.001)$. Serum MIOX level was higher in groups 2,3 and 4 than in group 1 $(p=0.002)$. Tissue MIOX level was lower in groups 2,4 , and 5 than in group $1(p=0.039)$. Serum and tissue neutrophil gelatinase-associated lipocalin levels were not significantly different between the groups. The injury level in histopathologic examination was as follows: group $1<$ group $3<$ group 2 =group $4<$ group 5 . CONCLUSION: The serum MIOX level increases in the early stages of AKI, however, decreases subsequently. Therefore, the serum MIOX may be a potential promising biomarker in the early diagnosis of AKI (Tab. 5, Fig. 6, Ref. 30). Text in PDF www.elis.sk KEY WORDS: renal ischemia-reperfusion; myo-inositol oxygenase; acute kidney injury; diagnostic biomarker; neutrophil gelatinase- associated lipocalin.

\section{Introduction}

Acute kidney injury (AKI) is a serious disease with high morbidity and mortality, especially in hospitalized patients (1). Increased serum creatinine level and decreased urine volume are two main parameters in the diagnosis of AKI. However, the use of serum creatinine alone leads to problems in the diagnosis because the creatinine level increases as late as after a $50 \%$ decrease in glomerular filtration rate (GFR) (2).

The plasma and urine level of interleukin (IL)-18, neutrophil gelatinase-associated lipocalin (NGAL) and kidney injury molecule 1 (KIM-1) can define AKI at its earlier stage without increasing serum creatinine. NGAL is a small protein from the lipocalin family, weighing $33 \mathrm{kD}$, and is expressed in renal tubule cells.

${ }^{1}$ Clinical Biochemistry, Faculty of Medicine, Erzincan Binali Yildirim University, Erzincan, Turkey, ${ }^{2}$ Clinical Biochemistry, Faculty of Medicine, Tokat Gaziosmanpasa University, Tokat, Turkey, ${ }^{3}$ Urology, Faculty of Medicine, Tokat Gaziosmanpasa University, Tokat, Turkey, and ${ }^{3}$ Pathology, Faculty of Medicine, Tokat Gaziosmanpasa University, Tokat, Turkey

Address for correspondence: C. Mertoglu, Dr, Department of Clinical Biochemistry, Mengücek Gazi Training and Research Hospital, Erzincan Binali Yildirim University, Erzincan, Turkey.

Phone: +90.5066377725 , Fax: +90.4462122200

Acknowledgement: This study was supported by Gaziosmanpasa University Scientific Research Projects Commission. (Project Number: 2015/123).
NGAL passes through urine and blood after tubular damage and is the most promising early diagnostic biomarker (3-6).

Myo-inositol oxygenase (MIOX) is the first enzyme in myoinositol (MI), a stereoisomer of inositol from sugar alcohols metabolism, and is mainly expressed in the kidneys. This is a unique pathway for MI catabolism (7-9). Although the MIOX enzyme is one of rare organ-specific enzymes, particularly a renal-specific enzyme, the data on the role of MIOX in the diagnosis of AKI are limited (9-11).

In this study, we investigated the role of MIOX enzyme in the diagnosis of AKI as an early biomarker as compared with NGAL, creatinine and blood urea nitrogen (BUN).

\section{Materials and methods}

In this study, a total of 40 male Wistar albino rats were used. Rats were fed standard pellet feed for rodents and water ad libitum, and housed in standard rat cages. Rats weighing between 300 $\mathrm{g}$ and $350 \mathrm{~g}$ were divided into 5 groups ( $\mathrm{n}=8$, for each group).

Group 1: The rats in this group were selected as a control group and no further action was performed.

Group 2: The rats in this group underwent 1 hour of ischemia and 2 hours of reperfusion,

Group 3: The rats in this group underwent 1 hour of ischemia and 4 hours of reperfusion, 
Tab. 1. Median and $95 \%$ CI values of biochemical parameters.

\begin{tabular}{|c|c|c|c|c|c|c|}
\hline \multirow{2}{*}{ Parameter } & \multicolumn{5}{|c|}{ Median 95\% CI } & \multirow{2}{*}{$\mathrm{P}$ value } \\
\hline & Group 1 & Group 2 & Group 3 & Group 4 & Group 5 & \\
\hline $\mathrm{BUN}$ & $18.2^{\text {bcde }}$ & $33.8^{\text {ae }}$ & $32.8^{\mathrm{ae}}$ & $32.0^{\text {ae }}$ & $43.3^{\mathrm{abcd}}$ & $<0.001$ \\
\hline$(\mathrm{mg} / \mathrm{dL})$ & $17.4-23.3$ & $31.3-37.2$ & $26.9-36.4$ & $29.2-35.1$ & $38.7-46.3$ & \\
\hline \multirow{2}{*}{$\begin{array}{l}\text { Creatinine } \\
(\mathrm{mg} / \mathrm{dL})\end{array}$} & $0.33^{\text {bcde }}$ & $0.74^{\text {ace }}$ & $0.46^{\text {abde }}$ & $0.65^{\text {ace }}$ & $0.87^{\text {abcd }}$ & $<0.001$ \\
\hline & $0.27-0.35$ & $0.61-0.84$ & $0.41-0.66$ & $0.59-0.72$ & $0.74-1.02$ & \\
\hline \multirow{2}{*}{$\begin{array}{l}\text { Glucose } \\
(\mathrm{mg} / \mathrm{dL})\end{array}$} & $252^{\mathrm{de}}$ & $291^{\mathrm{e}}$ & $252^{\mathrm{e}}$ & $291^{\text {ae }}$ & $501^{\text {abcd }}$ & $<0.001$ \\
\hline & $170-286$ & $230-365$ & $189-356$ & $251-391$ & $447-539$ & \\
\hline \multirow{2}{*}{$\begin{array}{l}\text { MIOX serum } \\
(\mathrm{ng} / \mathrm{mL})\end{array}$} & $1.63^{\mathrm{bcd}}$ & $3.21^{\text {acde }}$ & $2.72^{\mathrm{ab}}$ & $2.29^{\mathrm{ab}}$ & $2.04^{\mathrm{b}}$ & 0.002 \\
\hline & $1.58-2.22$ & $2.73-4.08$ & $2.14-2.99$ & $1.72-3.10$ & $1.39-2.99$ & \\
\hline \multirow{2}{*}{$\begin{array}{l}\text { MIOX tissue } \\
\text { (ng/g protein) }\end{array}$} & $57.2^{\text {bde }}$ & $43.4^{\mathrm{a}}$ & $51.3^{\mathrm{e}}$ & $43.7^{\mathrm{a}}$ & $38.5^{\mathrm{ac}}$ & 0.039 \\
\hline & $48.3-66.2$ & $26.1-52.2$ & $36.3-69.5$ & $34.5-53.2$ & $22.1-53.4$ & \\
\hline \multirow{2}{*}{$\begin{array}{l}\text { NGAL serum } \\
(\mathrm{pg} / \mathrm{mL})\end{array}$} & 1191 & 1585 & 1373 & 1433 & 1413 & 0.093 \\
\hline & $709-1374$ & $1159-1760$ & $1270-1439$ & $911-1712$ & $1310-1790$ & \\
\hline \multirow{2}{*}{$\begin{array}{l}\text { NGAL tissue } \\
\text { (pg/g protein) }\end{array}$} & 58.8 & 45.1 & 59.4 & 46.2 & 47.5 & 0.161 \\
\hline & $48.1-63.2$ & $34.5-60.3$ & $42.8-71.5$ & $37.2-59.8$ & $29.8-61.7$ & \\
\hline
\end{tabular}

Group 4: The rats in this group underwent 2 hours of ischemia and 2 hours of reperfusion,

Group 5: The rats in this group underwent 2 hours of ischemia and 4 hours of reperfusion.

Tab. 2. The results of receiver operating characteristic analysis.

\begin{tabular}{lcccc}
\hline Parameter & AUC & Cut-off & Sensitivity $(\%)$ & Specificity(\%) \\
\hline $\begin{array}{l}\text { BUN } \\
(\mathrm{mg} / \mathrm{dL})\end{array}$ & 1.000 & $>25.8$ & 100 & 100 \\
\hline $\begin{array}{l}\text { Creatinine } \\
(\mathrm{mg} / \mathrm{dL})\end{array}$ & 1.000 & $>0.36$ & 100 & 100 \\
\hline $\begin{array}{l}\text { MIOX serum } \\
\text { (ng/mL) }\end{array}$ & 0.633 & $>2.44$ & 43.75 & 100 \\
\hline $\begin{array}{l}\text { MIOX tissue } \\
\text { (ng/g protein) }\end{array}$ & 0.699 & $\leq 44.75$ & 56.25 & 100 \\
\hline $\begin{array}{l}\text { NGAL serum } \\
\text { (pg/mL) }\end{array}$ & 0.523 & $>1393$ & 40.63 & 87.5 \\
\hline $\begin{array}{l}\text { NGAL tissue } \\
\text { (pg/g protein) }\end{array}$ & 0.691 & $\leq 45.32$ & 56.25 & 100 \\
\hline
\end{tabular}

AUC - area under curve. BUN - blood urea nitrogen. NGAL - neutrophil gelatinaseassociated lipocalin. MIOX - myo-inositol oxygenase.

Tab. 3. Comparison of areas under the curve in receiver operating characteristic analysis.

\begin{tabular}{lccccc}
\hline Parameter & $\begin{array}{c}\text { Creatinine } \\
\text { "The difference } \\
\text { between AUC" } \\
\text { "p value" }\end{array}$ & $\begin{array}{c}\text { MIOX serum } \\
\text { "The difference } \\
\text { between AUC" } \\
\text { "p value" }\end{array}$ & $\begin{array}{c}\text { MIOXtissue } \\
\text { "The difference } \\
\text { between AUC" } \\
\text { "p value" }\end{array}$ & $\begin{array}{c}\text { NGAL serum } \\
\text { "The difference } \\
\text { between AUC" } \\
\text { "p value" }\end{array}$ & $\begin{array}{c}\text { NGALtissue } \\
\text { "The difference } \\
\text { between AUC" } \\
\text { "p value" }\end{array}$ \\
\hline BUN & 0.000 & 0.367 & 0.301 & 0.477 & 0.309 \\
(mg/dL) & 1.000 & $<\mathbf{0 . 0 0 1}^{\mathbf{a}}$ & $\mathbf{0 . 0 0 7}^{\mathbf{b}}$ & $<\mathbf{0 . 0 0 1}$ & $0.006 \mathrm{~b}$ \\
\hline Creatinine & & 0.367 & 0.301 & 0.477 & 0.309 \\
(mg/dL) & $<\mathbf{0 . 0 0 1}^{\mathbf{a}}$ & $\mathbf{0 . 0 0 7}^{\mathbf{b}}$ & $<\mathbf{0 . 0 0 1}^{\mathbf{a}}$ & $0.006 \mathrm{~b}$ \\
\hline MIOX serum & & 0.066 & 0.109 & 0.059 \\
(ng/mL) & & 0.571 & 0.264 & 0.629 \\
\hline MIOX tissue & & & 0.176 & 0.008 \\
(ng/g protein) & & & 0.106 & 0.860 \\
\hline NGAL serum & & & & 0.168 \\
(pg/mL) & & & & 0.144 \\
\hline
\end{tabular}

$\mathrm{a}-\mathrm{p}<0.001, \mathrm{~b}-\mathrm{p}<0.05$. AUC - area under curve, BUN - blood urea nitrogen, NGAL - neutrophil gelatinaseassociated lipocalin, MIOX - myo-inositol oxygenase
Blood and kidney tissue samples were taken after all animals had been anesthetised with $50 \mathrm{mg} / \mathrm{kg}$ ketamine and $10 \mathrm{mg} / \mathrm{kg}$ xylazine. The operation site of rats was cleaned with sterile povidone iodide in supine position, a mid-abdominal incision was made, and the renal artery was clamped at the hilus level by reaching the left kidney in groups 2, 3, 4 and 5. The clamped kidney was exposed to ischemia (ischemia was monitored by color change and absence of pulsation). When the ischemia period expired, the clamp was removed and reperfusion was performed (reperfusion was monitored in terms of color change and pulsation). In order to prevent dehydration due to the experiment, the operation area of the animals was covered with sponges soaked with sterile saline. One of the rats died due to anesthesia during the experiment. After reperfusion, blood and kidney tissues were taken and animals were sacrificed by means of the exsanguination method. The samples were delivered to the biochemistry laboratory as soon as possible for the study. The blood samples were centrifuged for 15 minutes at $1,500 \mathrm{~g}$ and the serum was separated and stored at $-80^{\circ} \mathrm{C}$ until the time of testing with the kidney tissue samples.

Some of the kidney tissue samples were fixed in $10 \%$ formaldehyde for histopathological evaluation and passed through the routine histological follow-up series and embedded in paraffin blocks. Paraffin block sections, 5 and $20 \mu \mathrm{m}$ thick, were laid on microscope slides. Hematoxyline and eosin staining of kidney tissue was performed. Quantitative measurements of tubulointerstitial damage were performed by evaluating the necrotic and apoptotic cell count, loss of tubular edge, tubular dilatation, and neutrophil formation. Histopathological results were evaluated as follows: $0=$ no damage, $1=0-10 \%, 2=$ $11-25 \%, 3=26-45 \%, 4=46-75 \%$ and 5 $=76-100 \%(12)$. 
Biochemical examination

Homogenization of kidney tissue

Kidney tissue is homogenized with $50 \mathrm{~mm}$ tris-HCI $(\mathrm{pH}=$ 7.4) buffer at $1 / 10$ ratio by using ice to prevent heat increase (13). MIOX and NGAL levels were measured from some of the prepared homogenates. The other part of the homogenates was centrifuged at $+4{ }^{\circ} \mathrm{C}$ at $3,500 \mathrm{rpm}$ for 30 minutes in a centrifuge to obtain supernatants and the tissue protein level was determined from these supernatants by the Lowry method (14).

MIOX and NGAL were measured from the serum and renal tissue homogenates by enzyme linked-immunosorbent Assay (ELISA). Serum BUN, creatinine and glucose levels were also measured by spectrophotometric automated biochemistry device (Cobas Roch, Germany).

\section{MIOX measurement}

Serum and tissue MIOX levels were analyzed with a rat MIOX ELISA Kit (Catalog number: E-EL-R2591, Elabscience, USA). The sensitivity of the used rat MIOX ELISA kit was specified as $0.10 \mathrm{ng} / \mathrm{mL}$, the measurement range was $0.16-10 \mathrm{ng} / \mathrm{mL}$, and $\mathrm{CV}$ was $<10 \%$.

\section{NGAL measurement}

Serum and tissue NGAL levels were measured using the rat NGAL ELISA Kit (Catalog number: E-EL-R0662, Elabscience, United States). The sensitivity of the used rat NGAL ELISA kit was reported to be $37.50 \mathrm{pg} / \mathrm{mL}$, the measurement range was $62.50-4000 \mathrm{ng} / \mathrm{mL}$, and $\mathrm{CV}$ was $<10 \%$.

\section{Statistical analysis}

The Kolmogorov-Smirnov test was used determine the normal distribution of each parameter. Comparisons of all groups were done by Kruskal-Wallis test first and then binary comparisons were performed with Mann-Whitney U test. SPSS, version 18.0 (SPSS, Chicago, IL, USA), was used for all statistical analyses. The results of the study were presented as median and $95 \%$ confidence interval (CI). The sensitivity, specificity, and cut-off values were analyzed using the Medcalc statistical software (13.2.0, Mariakerke, Belgium) using the receiver operating characteristics (ROC) curve analysis. A p value of less than 0.05 was accepted as statistically significant.

Tab. 4. The correlation table.

\begin{tabular}{lcccc}
\hline Parameter & MIOX serum & MIOX tissue & NGAL serum & NGAL tissue \\
\hline BUN & & & & \\
$\mathrm{p}$ & 0.205 & $0.009^{\mathrm{a}}$ & $0.012^{\mathrm{a}}$ & 0.074 \\
$\mathrm{r}$ & 0.237 & -0.435 & 0.473 & -0.285 \\
\hline Creatinine & & & & \\
$\mathrm{p}$ & 0.070 & $0.008^{\mathrm{a}}$ & $0.014^{\mathrm{a}}$ & 0.124 \\
$\mathrm{r}$ & 0.340 & -0.445 & 0.466 & -0.250 \\
\hline Glucose & & & & \\
$\mathrm{p}$ & 0.820 & $0.009^{\mathrm{a}}$ & 0.099 & 0.084 \\
$\mathrm{r}$ & -0.043 & -0.431 & 0.324 & -0.276 \\
\hline a $\mathrm{p}<0.05$. BUN - blood urea nitrogen. NGAL - neutrophil gelatinase-associated \\
lipocalin. MIOX v myo-inositol oxygenase.
\end{tabular}

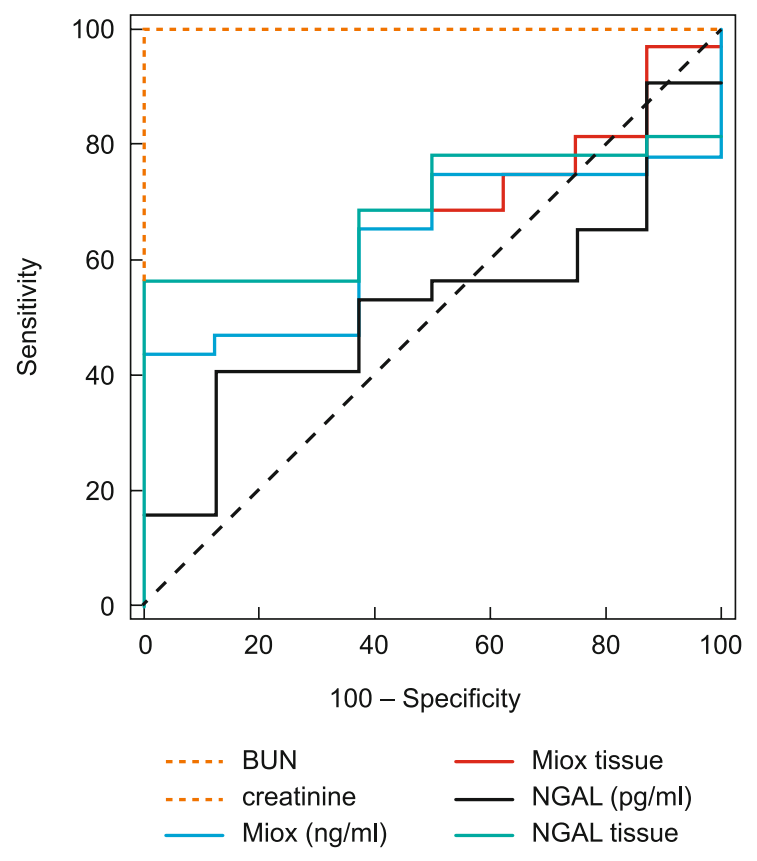

Fig. 1. The receiver operating characteristic (ROC) curve of the kidney injury markers in the diagnosis of acute kidney injury.

\section{Results}

BUN and creatinine levels were higher in all groups that underwent ischemia-reperfusion as compared to the control group (Tab. 1). Also, BUN and creatinine levels in group 5 were higher than in other ischemia-reperfusion groups $(p<0.001)$. However, there was no significant alteration in BUN between groups 2,3 and 4 . The levels of creatinine in groups 2 and 4 were higher than in group 3.

The levels of serum MIOX in the groups 3 and 4 were higher than in group $1(\mathrm{p}=0.002)$. The highest level of serum MIOX was found in Group 2. The levels of tissue MIOX in groups 2, 4 and 5 were lower compared to group 1 . The level of tissue MIOX in group 5 was also lower than in group $3(p=0.039)$. The levels of serum NGAL in ischemia-reperfusion groups were higher than in the control group but not statistically significant. Tissue NGAL levels decreased in groups 2, 4 and 5, as compared to group 1, but this difference was also not statistically significant. The highest serum glucose level was in group 5 while being higher in group 4 than in group 1.

The area under the curve (AUC) for BUN (cut-off $>25.8 \mathrm{mg} /$ $\mathrm{dL}$ ) and creatinine (cut-off $>0.36 \mathrm{mg} / \mathrm{dL}$ ) was 1 , and the sensitivity and specificity were $100 \%$, i.e. also significantly higher than for all other biomarkers in the ROC analysis. There is no difference in AUC comparison of the other biomarkers (Tabs 2 and 3, Fig. 1).

BUN, creatinine, and glucose levels negatively correlated with MIOX tissue level. Also, there was a positive correlation between serum NGAL level and levels of serum BUN and creatinine (Tab. 4).

Only groups 2 and 4 were similar and all other groups differed from each other in the left-kidney histopathological tissue score. 


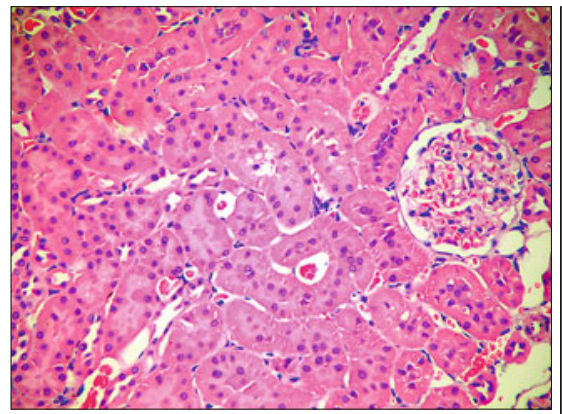

Fig. 2. Glomerular and tubular structures in normal morphology (Group 1).

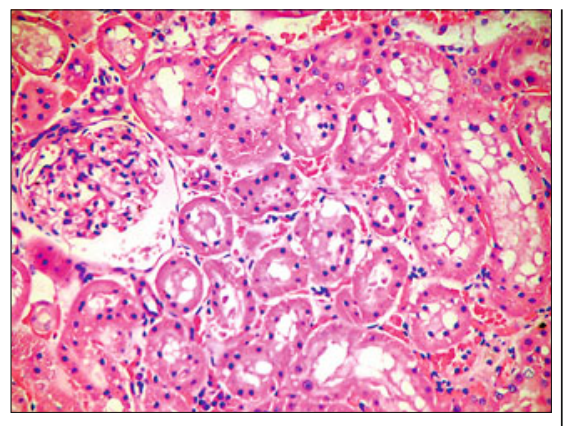

Fig. 5. Degeneration of tubular epithelial cells, expansion in Bowman's cavity, congestion in interstitial area (Group 4)

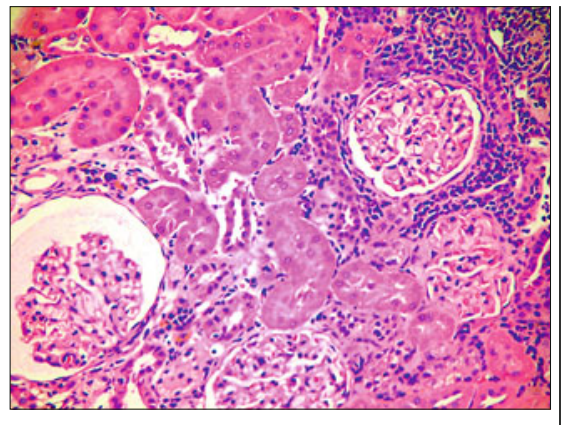

Fig. 3. Mild degeneration of tubular epithelial cells, expansion of Bowman's cavity, inflammatory cell infiltration in interstitial area (Group 2).

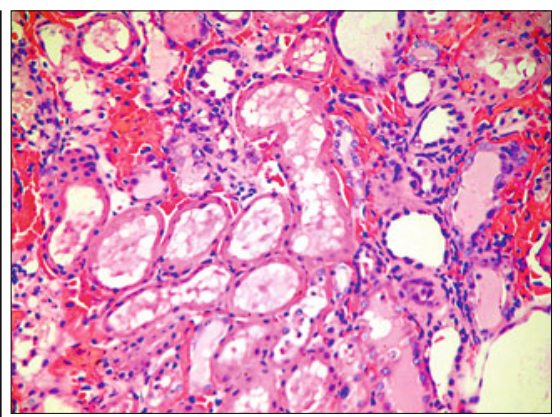

Fig. 6. Degeneration of tubular epithelial cells, fluid accumulation in tubular lumens, diffuse bleeding in the interstitial area and congestion (Group 5).

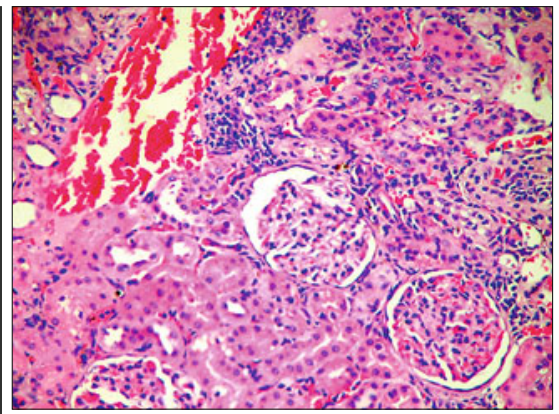

Fig. 4. Congestion and mild inflammatory infiltration in the interstitial area (Group 3).

and tissue MIOX and NGAL levels were compared with classical markers, serum creatinine and BUN levels, in the experimental renal ischemia-reperfusion injury.

The MIOX enzyme is involved in the pathways of carbohydrate metabolism (8). In recent years, the effectiveness of MIOX enzyme in the diagnosis of AKI has been a curious topic, especially due to its renal specificity $(9,10)$.

Gaut et al (9) has recently found out that MIOX enzyme is a biomarker that shows AKI in its early stages. In their study, rats underwent bilateral ischemia for 30 minutes and the MIOX level was

The damage level was as follows: group $1<$ group $3<$ group $2=$ Group $4<$ group 5 lower to high (Tab. 5). Illustrations show the histopathology of each group (Figs 2-6).

\section{Discussion}

Serum creatinine, BUN and urine output are late and non-sensitive markers of the AKI diagnosis (15). Therefore, the main objective of this study was the necessity of investigating new diagnostic biomarkers in the early diagnosis of AKI. For this purpose, serum

Tab. 5. Comparison of histopathological evaluation scores of the kidney tissues.

\begin{tabular}{cccccc}
\hline \multicolumn{5}{c}{ Tissue damage score } \\
\hline Subject & Group 1 & Group 2 & Group 3 & Group 4 & Group 5 \\
\hline 1 & 1 & 3 & 2 & 3 & 4 \\
2 & 1 & 3 & 2 & 3 & 3 \\
3 & 0 & 4 & 3 & 3 & 4 \\
4 & 0 & 3 & 2 & 3 & 4 \\
5 & 1 & 3 & 3 & 3 & 4 \\
6 & 0 & 3 & 2 & 3 & 4 \\
7 & 1 & 2 & 2 & 4 & 5 \\
8 & 0 & 3 & 3 & 3 & 4 \\
\hline Median & 0.5 & 3 & 2 & 3 & 4 \\
\hline Different & Group & Group & Group & Group & Group \\
groups * & $2,3,4,5$ & $1,3,5$ & $1,2,4,5$ & $1,3,5$ & $1,2,3,4$ \\
\hline p $<0.001$ & \multicolumn{5}{c}{}
\end{tabular}

measured after the surgery (experimental group $\mathrm{n}=6$, sham group $\mathrm{n}=2$ ). MIOX was not detected in mice before surgery and sham group, but the MIOX level was significantly increased at 24 hours after the ischemia. Also, critical patients were screened 24 to 72 hours before the development of AKI $(n=101)$ on the basis of an increase in plasma creatinine in the study. MIOX levels were measured from plasma taken before the increase in creatinine level and after the creatinine level had increased. In conclusion, they found that the plasma MIOX level increased 54.3 hours before creatinine. Furthermore, the specificity of the MIOX enzyme to the kidneys was demonstrated by western blotting technique in that study. In another recent study on human subjects from our research group, serum MIOX level was detected to be higher in the patient group with increased serum creatinine at the time of diagnosis of AKI than in the healthy control group (10). In another study, in which we investigated the effect of retrograde intrarenal surgery on kidney tissue in renal stone treatment, the serum MIOX level was found to be beneficial in showing renal damage. Moreover, there was a positive correlation between the levels of serum MIOX and creatinine in the same study (11).

Similar to the previous studies, the present study showed that serum MIOX level increases in the early stages of AKI. However, this increase is decreasing in the later hours of AKI. The highest level of serum MIOX was measured in the second group (with 1-hour ischemia and 2-hour reperfusion), and decreased in the later stage of the experiment, while the level of serum MIOX in 
group 5 (in which the reperfusion lasted for 4 hours) approached that in the control group. There should be a certain period of time for the occurrence of ischemia-reperfusion injury in the kidney. Paller et al (16) showed that the duration of ischemia for $60 \mathrm{minu}-$ tes was sufficient for ischemia-reperfusion injury to occur. Serum BUN and creatinine levels indicated adequate renal damage because they were higher in all ischemia-reperfusion groups as compared to the control group. The fact that the highest levels of BUN and creatinine were in group 5, indicates that the most severe kidney injury is in this group. The fact that the creatinine level in group 3 was lower than in group 2, suggests that the third group was in the process of healing of their kidney function. Both these groups were exposed to ischemia for 1 hour but group 2 was reperfused for 2 hours and the reperfusion period of group 3 was increased to 4 hours. However, the creatinine value was higher in group 5 whose reperfusion duration was longer than that in group 4, while the ischemia durations were the same and the reperfusion durations in groups 4 and 5 were different. Therefore, in cases where the ischemic injury was more severe, the loss of renal function is higher in contrast to the improvement in group 3. Also, the most severe damage was in group 5, later in groups 2 and 4, and later in group 3, while the damage in all ischemiareperfusion groups was higher than in the control group in histopathological examination. Therefore, histopathological results support the biochemical data.

The lower levels of tissue MIOX levels in groups 2, 4 and 5 as compared to group 1 may be due to the loss of function in the tubule cells due to kidney damage and/or passage of enzyme from disrupted cells into urine. In fact, in previous studies it has been reported that the passage of some enzymes released from the renal tubules into urine increased in response to ischemic or nephrotoxic damage $(17,18)$. However, the facts that the MIOX enzyme tissue level in group 3 was higher than in other experimental groups, and other parameters such as creatinine approached the level found in the control group, show that this group has started the healing process. In addition to one-hour ischemia, the four hours of reperfusion in the third group caused minimal damage and provided sufficient recovery time.

The relationship of MIOX with diseases other than AKI is also investigated. It was reported that hyperosmolar stress induced an overexpression of MIOX in diabetic nephropathy (19). Also, MIOX over-expression was attributed to different transcription factors of glucose-induced mediators and activated kinases in diabetic nephropathy (20). Another recent study (21) has shown that overexpression of MIOX is responsible for the overproduction of reactive oxygen species (ROS), which contributes to tubulointerstitial injury in obesity and diabetes mellitus. Moreover in a new study (22), MIOX overexpression increased renal injury in diabetic nephropathy due to oxidative stress, increased ROS, and led to distruption of antioxidant systems. Moreover, MIOX expression has been reported to be low in extra-renal organs with diabetic complications such as neuropathy, retinopathy, and cataract (23). Also, it has been suggested that a single nucleotide polymorphism (rs761745) seen in the promoter region of the MIOX gene is related to the development of type 1 diabetes mellitus (7).
In animal studies, it has been shown that NGAL does not increase effectively in circulation but is abundant in ipsilateral ureter after unilateral ischemia by ipsilateral renal vein clamp in the kidney (24). These results are similar to the results of the present study and explain the similarity in serum NGAL levels between the groups. As the animal studies were done on a small number of subjects compared to human studies, the partial number of subjects may have caused this result. This change in serum and tissue NGAL levels may be related to an increase in the passage of this protein from damaged kidney cells into urine as shown in previous studies $(18,24,25)$.

Delanaye et al (26) suggested to use NGAL/creatinine ratio due to the high rate of biological variation in urinary NGAL level. However, the biological variation of NGAL measurement remains very high even when the creatinine ratio is used. In addition, the studies evaluating the biological variation of NGAL have always been performed in healthy individuals and according to aour knowledge, no study investigating the exact variation of AKI patients has been conducted so far. Therefore, this large biological variation restricts the validity of NGAL in the diagnosis of AKI. However, Padhy et al (27) found serum NGAL level increased in contrast-induced AKI. In another study, plasma NGAL and cystatin c levels were claimed to be superior to traditional markers in predicting AKI after cardiac surgery (25).

The area under the curve (AUC) of creatinine and BUN were significantly higher than AUC of serum/tissue MIOX and serum/ tissue NGAL in the ROC analysis. So, serum creatinine and BUN are still the chief biomarkers in the AKI diagnosis. Also, serum/ tissue MIOX and serum/tissue NGAL values were found to have an important sensitivity and specificity in the AKI diagnosis.

The development of pancreatic damage secondary to renal ischemia-reperfusion in group 5, in which the the renal injury was the highest, might have caused the highest serum glucose level in that group. The fact that oxidative stress causes pancreatic damage secondary to renal ischemia-reperfusion has been already reported $(28,29)$.

One of the main problems with the early diagnosis markers of AKI is the fact they are measured by ELISA method which has low analytical sensitivity and thus yields very different cut-off values (4). Nevertheless, in the recent years, more reliable methods of measuring these markers, such as mass spectrometry, have been implemented. Moreover, the methods of measuring MIOX, phosphoenolpyruvate carboxinazase 1 (PCK1), NGAL and L-FABP markers by mass spectrometry have recently been described (30).

Urine could not be taken in this study due to small anatomical structure of rats. Thus, the inability to dedect urinary MIOX is a limitation of this study. Comprehensive human studies should be done in the future. Also, advanced measurement methods such as mass spectrometry should be used for measuring MIOX.

\section{Conclusion}

The serum MIOX level increases in the early stages of AKI, however decreases subsequently. Hence, the serum MIOX may be a promising potential diagnostic biomarker in the early diag- 
nosis of AKI. According to the results of this study, serum NGAL level is insufficient for indicating renal ischemia-reperfusion injury. Serum creatinine and BUN are still the chief biomarkers in the AKI diagnosis.

\section{References}

1. Hoste EAJ, Clermont G, Kersten A, Venkataraman R, Angus DC, De Bacquer $\mathbf{D}$ et al. RIFLE criteria for acute kidney injury are associated with hospital mortality in critically ill patients: a cohort analysis. Crit Care 2006; 10 (3): R73.

2. Waikar SS, Betensky RA, Bonventre J V. Creatinine as the gold standard for kidney injury biomarker studies. Vol. 24. Nephrology Dialysis Transplantation 2009: 3263-3265.

3. Siew ED, Ware LB, Ikizler TA. Biological markers of acute kidney injury. J Am Soc Nephrol 2011; 22 (5): 810-820.

4. Haase M, Bellomo R, Devarajan P, Schlattmann P, Haase-Fielitz A, Bagshaw SM et al. Accuracy of Neutrophil Gelatinase-Associated Lipocalin (NGAL) in Diagnosis and Prognosis in Acute Kidney Injury: A Systematic Review and Meta-analysis. Am J Kidney Dis 2009; 54 (6): 1012-1024.

5. Devarajan P. Neutrophil gelatinase-associated lipocalin: a promising biomarker for human acute kidney injury. Biomark Med 2010; 4 (2): 265-280.

6. Mertoglu C, Gunay M, Gurel A, Gungor M, Gul V. Ischemic modified albumin increases in acute kidney injury. Rev Rom Med Lab 2018; 26 (1).

7. Yang B, Hodgkinson A, Millward BA, Demaine AG. Polymorphisms of myo-inositol oxygenase gene are associated with Type 1 diabetes mellitus. J Diabetes Complications 2010; 24 (6): 404-408.

8. Arner RJ, Prabhu KS, Thompson JT, Hildenbrandt GR, Liken a D, Reddy CC. myo-Inositol oxygenase: molecular cloning and expression of a unique enzyme that oxidizes myo-inositol and D-chiro-inositol. Biochem J 2001; 360 (Pt 2): 313-320.

9. Gaut JP, Crimmins DL, Ohlendorf MF, Lockwood CM, Griest TA, Brada NA et al. Development of an immunoassay for the kidney-specific protein myo-inositol oxygenase, a potential biomarker of acute kidney injury. Clin Chem 2014; 60 (5): 747-757.

10. Mertoglu C, Gunay M, Gurel A, Gungor M. Myo-inositol oxygenase as a novel marker in the diagnosis of acute kidney injury. J Med Biochem 2018; 37.

11. Mertoglu C, Bozkurt A, Keskin E, Gunay M. Evaluation of the effect of retrograde intrarenal surgery with myo-inositol oxygenase. Pakistan J Med Sci 2018; 34 (1).

12. Kocoglu H, Ozturk H, Ozturk H, Yilmaz F, Gulcu N. Effect of dexmedetomidine on ischemia-reperfusion injury in rat kidney: A histopathologic study. Ren Fail 2009;

13. I.A. Klinik biyokimya laboratuari el kitabi. AkkuĢ Öz Eğitim Bas. Yay. Dağ. Konya; 1995. 1-354 p.

14. Lowry OH, Rosebrough NJ, Farr AL, Randall RJ. Protein measurement with the Folin phenol reagent. J Biol Chem. 1951;

15. Reiser IW PJ. Evaluation of renal function. In Massry SG, Glassock RJ, ed. Textbook of Nephrology, 4th ed, Philadelphia, Lippincott Williams \& Wilkins; 2001, 1793-1802 p.
16. Paller MS, Hoidal JR, Ferris TF. Oxygen free radicals in ischemic acute renal failure in the rat. J Clin Invest 1984; 74 (4): 1156-1164.

17. D’Amico G, Bazzi C. Urinary protein and enzyme excretion as markers of tubular damage. Curr Opinion Nephrol Hypertens 2003; 12: 639-643.

18. Waikar SS, Bonventre JV. Biomarkers for the diagnosis of acute kidney injury. Nephron Clin Pr 2008; 109 (4): c192-197.

19. Prabhu KS, Arner RJ, Vunta H, Reddy CC. Up-regulation of human myo-inositol oxygenase by hyperosmotic stress in renal proximal tubular epithelial cells. J Biol Chem 2005; 280 (20): 19895-19901.

20. Nayak B, Kondeti VK, Xie P, Lin S, Viswakarma N, Raparia K et al. Transcriptional and post-translational modulation of myo-inositol oxygenase by high glucose and related pathobiological stresses. J Biol Chem 2011; 286: 27594-27611.

21. Tominaga T, Dutta RK, Joladarashi D, Doi T, Reddy JK, Kanwar YS. Transcriptional and translational modulation of myo-inositol oxygenase (Miox) by fatty acids: Implications in renal tubular injury induced in obesity and diabetes. J Biol Chem 2016; 291: 1348-1367.

22. Sun L, Dutta RK, Xie P, Kanwar YS. myo-inositol oxygenase overexpression accentuates generation of reactive oxygen species and exacerbates cellular injury following high glucose ambience: A new mechanism relevant to the pathogenesis of diabetic nephropathy. J Biol Chem 2016; 291 (11): 5688-5707.

23. Arner RJ, Prabhu KS, Krishnan V, Johnson MC, Reddy CC. Expression of myo-inositol oxygenase in tissues susceptible to diabetic complications. Biochem Biophys Res Commun 2006; 339 (3): 816-820.

24. Schmidt-Ott KM, Mori K, Li JY, Kalandadze A, Cohen DJ, Devarajan $P$ et al. Dual action of neutrophil gelatinase-associated lipocalin. J Am Soc Nephrol 2007; 18 (2): 407-413.

25. Haase-Fielitz A, Bellomo R, Devarajan P, Story D, Matalanis G, Dragun $\mathbf{D}$ et al. Novel and conventional serum biomarkers predicting acute kidney injury in adult cardiac surgery - a prospective cohort study. Crit Care Med 2009; 37 (2): 553-560.

26. Delanaye P, Rozet E, Krzesinski JM, Cavalier E. Urinary NGAL measurement: Biological variation and ratio to creatinine. Clin Chim Acta 2011; 412: 390

27. Padhy M, Kaushik S, Girish MP, Mohapatra S, Shah S, Koner BC. Serum neutrophil gelatinase associated lipocalin (NGAL) and cystatin $\mathrm{C}$ as early predictors of contrast-induced acute kidney injury in patients undergoing percutaneous coronary intervention. Clin Chim Acta 2014; 435: 48-52.

28. Abogresha NM, Greish SM, Abdelaziz EZ, Khalil WF. Remote effect of kidney ischemia-reperfusion injury on pancreas: Role of oxidative stress and mitochondrial apoptosis. Arch Med Sci 2016; 12 (2): 252-262.

29. Hussein AAM, Abd-Elkhabir A, Abozahra A, Baiomy A, Ashamallah SA, Sheashaa HA et al. Pancreatic injury secondary to renal ischemia/reperfusion (I/R) injury: Possible role of oxidative stress. Physiol Res 2014; 63 (1): 47-55.

30. Gilquin B, Louwagie M, Jaquinod M, Cez A, Picard G, El Kholy L et al. Multiplex and accurate quantification of acute kidney injury biomarker candidates in urine using Protein Standard Absolute Quantification (PSAQ) and targeted proteomics. Talanta 2017; 164: 77-84.

Received March 11, 2020. Accepted April 1, 2020. 